\title{
QUANTIFICATION AND DISTRIBUTION OF CIRCUMVALLATE LINGUAL PAPILLAE IN SAANEN GOATS
}

\author{
QUANTIFICAÇÃO E DISTRIBUIÇÃO DAS PAPILAS CIRCUNVALADAS DE \\ CAPRINOS DA RAÇA SAANEN
}

\begin{abstract}
Rogério Magno do Vale BARROSO ${ }^{1}$; Paula de Oliveira BRAGA ${ }^{2}$; Henrique Passos TABOSA ${ }^{2}$; André Luiz Quagliatto SANTOS ${ }^{3}$; Raphael Ribeiro SCHERER ${ }^{2}$; Paulo Oldemar SCHERER ${ }^{4}$; Marcelo Abidu FIGUEIREDO ${ }^{4}$; Ednaldo Carvalho GUIMARAES ${ }^{3}$

1. Curso de Medicina Veterinária da Universidade Federal do Acre, Rio Branco, AC, Brasil. vetbarroso@ yahoo.com.br ; 2. Médicos Veterinários Autônomos; 3. Universidade Federal de Uberlândia- UFU, Uberlândia, MG, Brasil; 4. Faculdade de Medicina Veterinária - UFRRJ- Seropédica, RJ, Brasil.
\end{abstract}

\begin{abstract}
The present study aimed to describe the disposition and amount of circumvallate lingual papillae in Saanen goats using 26 goat tongues from the Laboratory of Animal Anatomy and Morphology of the Federal Rural University of Rio de Janeiro, which were previously fixed in 10\% formaldehyde solution for later dissection of tongues that were removed from the oral cavity for the necessary studies. After identification, morphometric data were tabulated and submitted to statistical analysis for further description. In descriptive statistics, the mean of 17.85 was close to the median of 17.5 and the overall dispersion (standard deviation) was relatively low (2.24), which represents a coefficient of variation (CV) of $12.8 \%$. Confidence interval for mean with $95 \%$ with $99 \%$ confidence was also performed. Regarding the distribution of papillae, 21 tongues $(80.7 \%)$ of the total samples were located on the side of the tongue root, 3 tongues $(11.5 \%)$ were distributed on the side of the tongue root, migrating toward the tongue median sagittal plane, 1 tongue (3.8 $\%$ ) was located in the concave position on the side of the tongue root and 1 tongue $(3.8 \%)$ was disposed on the sides of the tongue, with some papillae arranged close to the region of the tongue median sagittal plane.
\end{abstract}

KEYWORDS: Anatomy. Small ruminants. Tongue.

\section{INTRODUCTION}

The goat farming in Brazil is increasingly consolidated as an important alternative for livestock with emphasis on small producers that use family labor (GONÇALVES et al., 2001).

Many factors have contributed to the consolidation of the Brazilian goat activity. In regions of northeastern Brazil, this activity is mainly due to the fact that these areas have semi-arid climate, which is considered excellent for farmers due to the strength and adaptability of goats to adverse weather conditions (GONÇALVES et al., 2001). However, the main factor that has contributed to the growth of goat production in the country is a great demand for goat products such as meat, milk and dairy products because they are healthier, thus leading to greater valuation of goat products and higher incomes for producers (SILVA et al., 2010).

High-production animals have higher nutrient requirements, mainly energy, for the demands of high productivity indexes (GONÇALVES et al., 2001). Thus, production efficiency is partly determined by feed efficiency and food consumption. Among the parameters used to evaluate consumption efficiency and the optimal operation of structures for such activity, tongue stands out, which is an important organ in the feeding activity of animals, with taste and food seizure functions, since taste is a major sensory properties, being decisive in food selection, acceptance and intake (COSTA et al., 2009).

The tongue occupies most of the oral cavity, but also extends to the oropharynx. It displays root and fixed body, mobile apex and robust musculature (DYCE et al., 2010). It is located on the mouth floor between the jaw branches and has the function of capturing and handling food and water, swallowing, hygiene and also acts as a sensory organ, being primarily composed of skeletal muscle (KÖNIG; LIEBICH, 2011; SISSON; GROSSMAN, 2012). Tongue may vary in shape, size and functionality, presenting such morphological diversity under strong influence of dietary habits (DORAN, 1975; DYCE et al., 2010; FONSECA et al., 2011; KOKUBUN et al., 2012).

Its mucosa is covered with sensors for tasting and sensitivity, called papillae, which can be divided into two groups. Mechanical papillae that assist licking and protect the deeper structures from injuries, composed of filiform, conical and marginal papillae; and tasting papillae, which are covered by gustatory buttons and are composed of fungiform, 
circumvallate and foliate papillae (KÖNIG; LIEBICH, 2011).

The distribution, size, quantity and form of papillae are an important factor in the differentiation of species. Therefore, it is noteworthy that the morphology of the lingual epithelium may undergo changes.

In goats, these papillae are soft and the tongue is relatively smooth compared to cattle. Their circumvallate papillae form an irregular double row on either side of the caudal part of the tongue dorsum (SISSON; GROSSMAN, 2012).

The circumvallated papillae, together with fungiform and foliate papillae, are related to the sensory perceptions related to taste. Generally, circumvallated papillae are located on the caudal third of the tongue root dorsal surface, on the lateral surface of the most caudal part of the lingual torus. In domestic mammals, these papillae are surrounded by a sulcus that follows their specific form, and within this sulcus, some ducts emerge from serous glands, which contribute to maintain the cleaning of this groove from the secretion of these glands. These grooves contain the structures responsible for the gustatory function, which is given by the taste buds present on the lateral wall that open in the sulcus of the papilla (DYCE, 2004; GUIMARÃES et al., 2007; FONSECA et al., 2011).

Its innervation results from bundles of nerve fibers from the deep part of the subepithelial connective tissue. Such sensory nerve fibers reach the connective tissue of the papilla, suffering several subdivisions in other branches, close to the basal epithelial cells. On the other hand, the bundles of nerve fibers of the circumvallated papilla present variability in their branches, giving rise to a complex mesh of sensorial terminals. The presence of these afferent nerve fibers is responsible for achieving the sensory impulse in the tongue mucosa (WATANABE et al, 2009).

Given its importance as production animal of oldest domestication and worldwide distribution (FONSECA et al., 2011), more detailed morphological studies providing data of greater clinical and surgical acuity should be conducted for improving technical practices performed in the goat activity.

Due to the importance of the goat activity as a source of fine food for humans, especially for those living in arid and semi-arid regions and also to the great adaptability of these animals to these ecosystems, it is important to better understand and describe the morphological characteristics of this species, seeking new and possibly unique aspects related to the distribution and quantification of papillae on the tongue of Saanen goats, aiming to seek a correct approach toward a rational exploitation of these animals. Studies may contribute with morphological information to aid in surgical procedures in addition to providing the development of the Comparative Anatomy, since much of the literature cited only brings generic information due to the fact that the data presented are specific to small ruminants.

Thus, the aim of this study was to count circumvallate papillae, to describe their amount and disposition on tongues of Saanen goats and to report differences in the disposition of this gland, based on existing literature.

\section{MATERIAL AND METHODS}

This study used tongues of twenty six domestic Saanen goats from the Laboratory of Animal Anatomy and Morphology of the Federal Rural University of Rio de Janeiro (UFRRJ) and approved by the ethics committee on animal use of the UFRRJ under number 0027773 14/05/2014. The animals were obtained from experimental slaughters performed at the Institute of Animal Science at the same institution. Their heads were previously fixed in $10 \%$ formaldehyde solution for posterior tongue dissection, which were taken from the oral cavity and photographed with digital camera. After identification, their data of counting and disposal of circumvallate papillae were tabulated and described. Schematic drawings as those of Guimarães et al. (2007) were performed to facilitate identification and location of papillae on the tongue region.

The results obtained were tabulated and submitted to statistical analysis by applying the Anderson-Darling normality test to verify if differences had normal distribution or not. Later, the nonparametric Wilcoxon test for paired data was used. Descriptive statistics considering all situations was also performed. All procedures were performed in the Action software that uses the R software and BioEstat software recommended by the $\mathrm{R}$ Development Core Team (2014) and Ayres et al. (2007), respectively.

\section{RESULTS}

In the papillae distribution, of the total samples, 21 tongues $(80.7 \%)$ were located on the side of the tongue root, 3 tongues $(11.5 \%)$ were distributed on the side of the tongue root, migrating toward the tongue median sagittal plane, 1 tongue $(3.8 \%)$ was located in the concave position on the side of the tongue root and 1 tongue $(3.8 \%)$ was 
disposed on the sides of the tongue, with some papillae arranged close to the region of the tongue median sagittal plane, as shown in Figure 1.

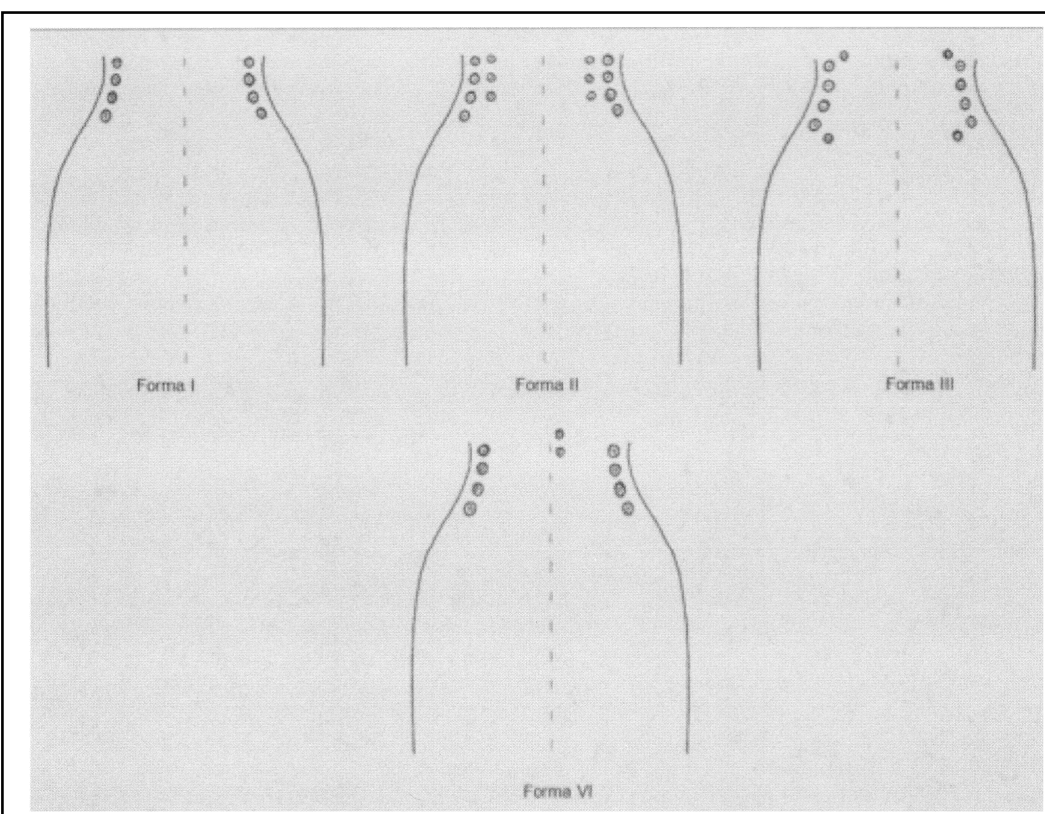

Figure 1. Schematic drawing of the goat tongue showing the location of circumvallate papillae and disposition according to the distribution found.

As for the number of papillae, the result of the Wilcoxon test showed p-value $=0.5955$, indicating that the number of papillae on the left side is equal to the right side. In the descriptive statistics, the mean of 17.85 was close to the median of 17.5 and the overall dispersion (standard deviation) was relatively low (2.24), representing a coefficient of variation (CV) of $12.8 \%$. Confidence interval for mean with $95 \%$ with $99 \%$ confidence was also performed. In relation to the shape, papillae were rounded to slightly oval, with the presence of a deep groove.

This result showed no significant variation in the number of papillae between sides. Thus, the analysis of animals confirms that the number of papillae on the right edge is equal to the number found on the left side.

\section{DISCUSSION}

The results showed the characteristics of the papillae of Saanen goats such as their number and distribution. The tongue surface showed papillae distributed throughout the side surface of the tongue root, at the tongue torus region, with differences in the amount and distribution, differing in distribution in each side of the dorsal caudal part, as reported in literature by Sisson and Grossman (2012). The presence and distribution of circumvallate papillae in most tongues of 26 Saanen goats studied was similar to of Mazama americana deer (KOKUBUN et al., 2012). Studies performed by Fonseca et al. (2011) with goats of the same breed and of Mazama americana deer (KOKUBUN et al., 2012). As in Saanen goats, boars of the Sus scrofa species have similarly arranged grooved papillae, being arranged only in the caudal region of the tongue dorsum (REGINATO, 2015). However, the existence of circumvallating papillae also in the lateral surface of the tongue root lingual torus was observed in goats.

The rounded shape presented in the papillae of this study was different from those found in other hebivores such as the Pantanal deer, having a flattened shape and mouse deers, which had flat and elongated papillae (AGUNGPRIYONO et al., 1995; MACHADO, 2016).

Regarding the number of circumvallate papillae found in this study, a minimum number of 14 papillae on the left and right sides of the tongue, and a maximum number of 23 and 22, respectively, on the left and right sides was identified, similar to the number of papillae found in water buffalo, 
which had a total of 23 circumferential papillae (CAN AND ATALGIN, 2015).Unlike the results of Sisson and Grossman (2012), which show a minimum number of 8 and maximum of 17 papillae for goats. It is noteworthy that the larger number of papillae found on both sides, left and right, was found in the same animal.

The characteristics presented in this study show large discrepancies regarding the amount of circumvallate papillae and their distribution on the tongue as reported by Sisson and Grossman (2012). These differences may be related to the type of diet offered to these animals, and it is noteworthy that the morphology of the lingual epithelium may vary according to diet, mechanical factors and food passage, thus affecting the tongue structure (FONSECA et al., 2011; ZHENG; KOBAYASHI, 2006).

Details about goat tongue are scarce in literature, even being a widespread and commercially used species. The results obtained in this study proved to be different from those in literature, and literature data for this species on some features addressed in this study are scarce.

\section{CONCLUSIONS}

This study showed that the number of papillae found on the right antimere is equal to the number found on the left antimere. Regarding distribution, more than half of the total samples analyzed $(80.7 \%)$ had symmetrical distribution on the sides of the tongue root lateral region.

Small variations in the number and / or distribution of papillae among animals is linked to the type of diet to which they were exposed and their feeding habits. Therefore, there is no variation with which a pattern can be established.

RESUMO: O presente estudo objetivou descrever a disposição e quantidade das papilas circunvaladas das línguas de cabras da raça Saanen, utilizando línguas de 26 cabras da raça, provenientes do Laboratório de Anatomia e Morfologia Animal da Universidade Federal Rural do Rio de Janeiro, que foram fixadas previamente em solução de formaldeído a $10 \%$ para posterior dissecção das línguas que foram retiradas da cavidade oral para os estudos necessários. Após identificação, os dados morfométricos foram tabulados e submetidos à análise estatística para posterior descrição. Na estatística descritiva, a média de 17,85 ficou próxima da mediana de 17,5 e a dispersão geral (desvio padrão) foi relativamente baixo $(2,24)$ que representa um coeficiente de variação $(\mathrm{CV})$ de $12,8 \%$. Também foi feito o Intervalo de Confiança para a média com $95 \%$ e com $99 \%$ de confiança. Em relação a distribuição, à forma de distribuição das papilas, 21 línguas $(80,7 \%)$ do total de amostras apresentadas encontravam-se dispostas nas laterais da raiz da língua, 3 línguas $(11,5 \%)$, apresentavam distribuição nas laterais da raiz da língua migrando em direção ao plano sagital mediano da língua, 1 língua $(3,8 \%)$ apresentava-se disposta de forma côncava nas laterais da raiz da língua e 1 língua $(3,8 \%)$ encontrava-se disposta nas laterais da língua, com algumas papilas dispostas próximo a região do plano sagital mediano da língua.

PALAVRAS-CHAVE: Anatomia. Pequenos ruminantes. Língua.

\section{REFERENCES}

AGUNGPRIYONO, S. et al. Morphology of the dorsal lingual papillae in the lesser mouse deer Tragulus javanicus. 187:635-640, 1995.

AYRES, M.; AYRES Jr, J. Anat. M.; AYRES, D. L.; SANTOS, A. S. dos. BioEstat 5.0: Aplicações estatísticas nas áreas das ciências biológicas e médicas. Belém: Sociedade Civil Mamirauá; Brasília: CNPq, p.364, 2007.

CAN, M.; ATALGIN, S. H. Scanning Electron Microscopic Study of the Lingual Papillae in the Anatolian Water Buffalo. J. Morphol., v. 33, n. 3, p. 855-859, 2015. https://doi.org/10.4067/S0717-95022015000300008

COSTA, R. G.; QUEIROGA, R. C. R. E.; PEREIRA, R. A. G. Influência do alimento na produção e qualidade do leite de cabra. R. Bras. Zootec., v. 38, p. 307-321, 2009. https://doi.org/10.1590/S1516-

35982009001300031 
DORAN, G. A. Review of the evolution and phylogeny of the mammalian tongue. Acta Anat., v. 91, p. 118129, 1975. https://doi.org/10.1159/000144377

DYCE, K. M.; SACK, W. O.; WENSING, C. J. G. Tratado de anatomia veterinária. 3.ed. Rio de Janeiro: Elsevier, p. 872., 2004.

FONSECA, E. T.; OLIVEIRA, C. M.; FRANCIOLLI, A. L. R.; MIGLINO, M. A. Características das papilas do dorso da língua de cabras (Capra hircus): estudo por de microscopia eletrônica de varredura e luz. Pesq. Vet. Bras., v. 31, p. 67-73, 2011. https://doi.org/10.1590/S0100-736X2011001300011

GONCALVES, A. L.; LANA, R. P.; RODRIGUES, M. T. et al. Padrão nictemeral do ph ruminal e comportamento alimentar de cabras leiteiras alimentadas com dietas contendo diferentes relações volumoso: concentrado. R. Bras. Zootec., v. 30, p. 1886-1892, 2001. https://doi.org/10.1590/S1516-35982001000700027

GONÇALVES, H. C.; SILVA, M. A.; WECHSLER, F. S.; RAMOS, A. Fatores genéticos e de meio na produção de leite de caprinos leiteiros. R. Bras. Zootec., v. 30, p. 719-729, 2001. https://doi.org/10.1590/S1516-35982001000300017

GUIMARÃES, G. C. et al. Anatomic study and distribution of the Vallate papillae in domestic cats. Braz. J. vet. Res. anim. Sci., São Paulo, v. 44, suplemento, p. 82-88, 2007.

GUIMARÃES, G. C.; MACHADO, M. R. F.; SANTOS QUAGLIATTO, A. L. Q. Morfologia, topografia e distribuição das papilas linguais valadas em equinos (equuscaballus, linnaeus, 1758) sem raça definida. Biosci. J., v. 23, p. 105-110, 2007.

KOKUBUN, H. S.; ESPER, G. V. Z.; FRANCIOLLI, A. L. R. et al. Estudo histológico e comparativo das papilas linguais dos cervídeos Mazama americana e Mazama gouzoubira por microscopia de luz e eletrônica de varredura. Pesq. Vet. Bras., v. 32, p. 1061-1066, 2012. https://doi.org/10.1590/S0100-736X2012001000021

KÖNIG, H. E.; LIEBICH H-G. Anatomia dos animais domésticos: Texto e atlas colorido. 4.ed. Porto Alegre: Artmed,. v. 2, p. 323-325, 2011.

OSMARI, E. K.; CECATO, U.; MACEDO, F. A. F. et al. Consumo de volumosos, produção e composição físico-química do leite de cabras F1 Boer $\times$ Saanen. R. Bras. Zootec., v. 38, p. 2473-2481, 2009. https://doi.org/10.1590/S1516-35982009001200025

QUEIROGA, R. C. R. E.; COSTA, R. G.; BISCONTINI, T. M. B. et al. Influência do manejo do rebanho, das condições higiênicas da ordenha e da fase de lactação na composição química do leite de cabras Saanen. $\mathbf{R}$.

Bras. Zootec., v. 36, p. 430-437, 2007. https://doi.org/10.1590/S1516-35982007000200021

MACHADO, M. R. F. et al. Morfologia da língua do cervo do pantanal (Blastocerus dichotomus) Pesq. Vet. Bras. v. 36, n. 4, p. 351-355, 2016. https://doi.org/10.1590/S0100-736X2016000400016

R DEVELOPMENT CORE TEAM. R: A language and environment for statistical computing. R Foundation for Statistical Computing, Vienna, 2013. Available from: <http://www.r-project.org/isbn 3- 900051-07-0>. Access on: 6 feb. 2014.

REGINATO, G. S. Características morfológicas estruturais e ultraestruturais da língua do javali (SUS scrofa). Dissertação (Mestrado) - Universidade de São Paulo. Faculdade de Medicina Veterinária e Zootecnia: São Paulo, 2015.

RESENDE, K. T.; TOSETTO, E. M. Avaliação de estratégias de manejo em criatórios de caprinos leiteiros. In: ENCONTRO NACIONAL PARA O DESENVOLVIMENTO DA ESPÉCIE CAPRINA, 8., 2004, Botucatu. Anais... Botucatu: UNESP/ FMVZ, [s.n.] 2004. p.184-198 (Resumo). 
SARMENTO, J. L. R.; REIS FILHO, J. C.; ALBUQUERQUE, L. G. et al. Avaliação genética de caprinos da raça Alpina utilizando-se a produção de leite no dia do controle. R. Bras. Zootec., v. 35, p. 443-451, 2006. https://doi.org/10.1590/S1516-35982006000200015

SILVA, G. L. S.; SILVA, A. M. A.; NÓBREGA, G. H. et al. Efeito da inclusão de fontes lipídicas na dieta de cabras em lactação sobre os parâmetros sanguíneos. Ciênc. Agrotec., v. 34, p. 233-239, 2010.

https://doi.org/10.1590/S1413-70542010000100030

SISSON, S. In: SISSON, S.; GROSSMAN, J. D. Anatomia dos Animais Domésticos. 5.ed. Rio de Janeiro: Guanabara Koogan, v. 1, p. 811, 2012.

WATANABE, I. et al. Nerve endings of filliform, fungiform and vallate papillae of dorsal tongue mucosa of White-lipped peccary (Tayassu pecari): Neurohistological observations. Pesq. Vet. Bras. v. 29, n. 4, p. 281285, 2009. https://doi.org/10.1590/S0100-736X2009000400001

ZHENG, J.; KOBAYASHI, K. Comparative morphological study on the lingual papillae and their connective tissue cores (CTC) in reeves'mutjac deer (Muntiacusreevesi). Ann. Anat., v. 188, p. 555-565, 2006. https://doi.org/10.1016/j.aanat.2006.05.014 